\title{
CHARACTERISTICS OF TUNA, SMALL TUNA AND SKIPJACK (TTS) FISHERY IN KUTARAJA OCEAN FISHING PORT, ACEH
}

\author{
Gussasta L. Arnenda*, Fathur Rochman \\ ${ }^{1}$ Research Institute of Tuna Fisheries \\ Email : gussastaarnenda@gmail.com
}

Received : 4 May 2021, Accepted: 24 July 2021

\begin{abstract}
Kutaraja Ocean Fishery Port is the oldest port in Banda Aceh City, Lampulo. Fishery resources are a new potential in the regional economic development of Aceh province. Fish resources that have great potential are from the large pelagic fish groups, including Tuna, Small Tuna and Skipjack (TTS) . Fishery characteristics are used to carry out sustainable fishing. This research was conducted at PPS Kuta Raja, Aceh for one year. Data collection was carried out directly through site surveys and interviews with related fisheries actors. Biological data and capturing aspects were carried out using a stratifield random sampling system by placing enumerators. The results showed that the production of TCT at PPS Kutaraja was dominated by 2 fishing gears, purse seine and hand lines. Based on the results of enumeration in 2020, the estimated total production of tuna skipjack and small tuna at PPS Kuta Raja reaches 11,520 tons. The highest total estimated fish catch is skipjack tuna (Katsuwonus pelamis) (SKJ) 5,802 tons, Bullet tuna (Auxis rochei)(BLT) 2814 tons, Yellow fin (Thunnus albacares) (YFT) 2,452 tons, Krai Tongkol (Auxis thazard) (FRI) 448 tons, and Eastern little tuna (Euthynnus affinis) (KAW) 1,745 tonnes. All of the fish caught were dominated by immature fish. So it is very necessary to evaluate the use of fishing gear or the licensing of FADs. The monthly CPUE distribution pattern is the same, where in August it reaches the highest CPUE and in October it reaches the lowest CPUE value.
\end{abstract}

Keywords: Biology; Catch Per Unit effort; fishing gear; little tuna; Skipjack

\section{INTRODUCTION}

Kutaraja Ocean Fishing Port, previously known as PP Lampulo, is a Type A fishing port. Kutaraja Ocean Fishing Port is the oldest port in Banda Aceh City, PP Lampulo. Fishery resources are a new potential that needs to be developed in the regional economic development of Aceh province (Juanda \& Martunis, 2014). Aceh waters is one of the areas with high fish potential because it is located on the northern tip of Sumatra Island which is bordered by three of the world's main marine waters, namely: the Indian Ocean, Andaman Sea and the Strait of Malacca (Herdiana et al., 2010). Marine fishery production in Banda Aceh City uses fishing gear that does not pay attention to biological aspects (Aprilia, Mustaruddin, Wiyono, \& Zulbainarni, 2013). So that the success of catching is very much influenced by the level of fishing effort made by fishermen (McCluskey dan Lewison, 2008).

Fish resources that have great potential are from large pelagic fish groups including Tuna, Small Tuna and Skipjack(TTS) (Firdaus, 2019). TTS owned by Aceh are fishery products skipjack tuna (Katsuwonus pelamis) (SKJ), Bullet tuna (Auxis rochei)(BLT), Yellow fin (Thunnus albacares) (YFT), Krai Tongkol (Auxis thazard) (FRI), and Eastern little tuna (Euthynnus affinis) (KAW) (Aprilia et al., 2013). The fishing gears used are gill nets, payang tonda, and purse seines (Mertha, Nurhuda, \& Nasrullah, 2017). The sustainability offishery activities IS TTS strongly influenced by the value chain system built by TTS business actors, one of which is understanding the characteristics of its role in carrying out sustainable fishing (Supriatna et al., 2014).
The aim of this research is to know the characteristics of tuna tuna fisheries which are recorded in PPS Kuta Raja in terms of fishing, production estimation, catch per nit effort, growth pattern and length distribution. So that fishing based on PPP Kuta Raja can be managed for sustainable catchers.

\section{RESEARCH METHODS}

This research was conducted at PPS Kuta Raja, Aceh. The research was carried out for one year except in May-June due to the constraints of the Covid-19 pandemic. Data collection was carried out directly through site surveys and interviews with related fisheries actors. The data collected in the study included: species composition of the catch, estimates, CPUE, length distribution and biological data. Biological data and aspects of capture were carried out using a stratifield random sampling (a method of sampling that involves the division of a population into smaller sub-groups known as strata) system by placing enumerators at the research location for daily data collection. Secondary data were obtained from logbooks and data from PPS Kuta Raja harbormaster. . The total number of fish samples measured by the skipjack tuna (Katsuwonus pelamis) (SKJ) as many as 3034 samples, Bullet tuna (Auxis rochei)(BLT) as many as 1073 samples, Yellow fin (Thunnus albacares) (YFT) as many as 1314 samples, Tongkol Krai (Auxis thazard) (FRI) as many as 636 samples, and Eastern little tuna (Euthynnus affinis) as many as 47 samples. The yuwana (juvenile) proportion indicator is the percentage of fish that has a length (cm) below the length of the fish that first matured gonads or often referred to as Lm (length at first maturity). 


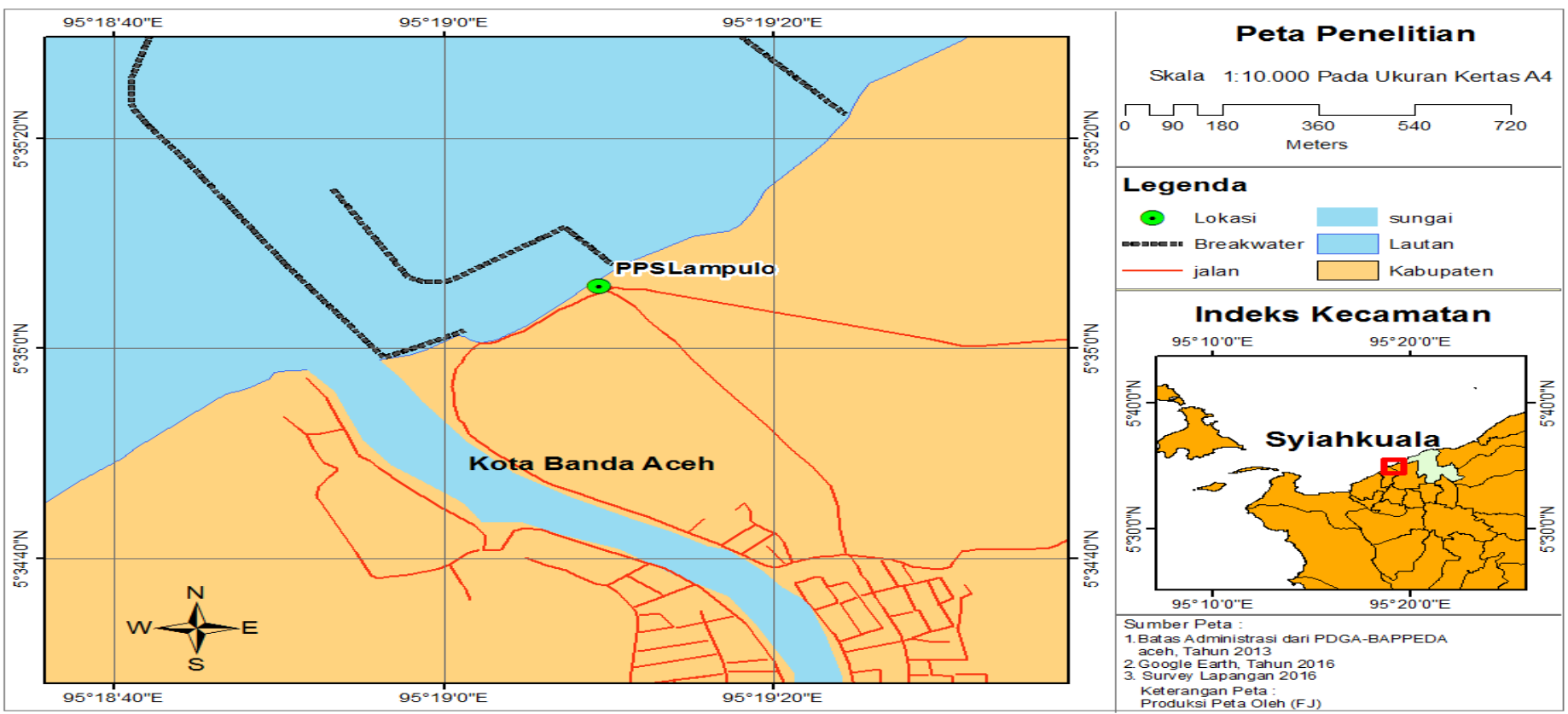

Figure 1. Location of Kutaraja Ocean Fishing Port (source :PPS Kuta Raja)

\section{Data Analysis}

Growth analysis using parameters of length and weight, with a linear regression approach, the relationship between the two parameters can be seen with the formula. The parameter correlation of the length and weight relationship can be seen from the constant value b. Fish length-weight relationships were analyzed separately between fish (male and female) (Liestiana, Ghofar, \& Rudiyanti, 2015)The length weight equation can also be calculated using the exponential equation, The formula:$$
\mathbf{W}=\mathbf{a} \mathbf{L}^{\mathrm{b}}
$$

Where: $\mathrm{W}=$ Weight $(\mathrm{g}) ; \mathrm{L}=$ Fork length $(\mathrm{cmFL}) ; \mathrm{a}=$ Intercept (the intersection of the weight-length relation curve to the $y$-axis) $; b=$ Slope (angle of slope of the regression line).

Catch estimation is done by taking into account the presence of fish per company per month. The calculation of the estimated total fish catch is as follows (Moreno, Guillermo;Herrera, 2013)

$$
C M=L M x A V M
$$

Where: $\mathrm{CM}=$ Total estimated fish catch per month (tonnes) ;LM = Number of ships landing fish per month at companies that landed fish (units); AVM = Average catch per month (Amount of fish catch enumerated (tonnes) ) / Number of vessels enumerated at companies that land fish (units)

The use of CPUE as an abundance index has long been used in quantitative fisheries analysis The equations used to calculate CPUE (Maunder et al., 2006) are:

$$
\text { CPUE }=\frac{C}{E}
$$

Where: $\mathrm{C}=\operatorname{catch}($ catch $=\mathrm{Kg}) ; \mathrm{E}=$ effort $($ effort $=$ ship $)$

\section{RESULT AND DISCUSSION}

\section{Technical aspects of fishing}

Large-scale tuna are mostly carried out in the Indian Ocean region of West Sumatra which is concentrated in Padang, Banda Aceh and partly in southern Java which is concentrated in the Pelabuhan Ratu-Sukabumi, Cilacap, PrigiTrenggalek, Sendang Biru-Malang and Benoa Bali. Purse seine is a type of fishing gear used by small and large scale fishermen / industry to catch small and large pelagic (Jatmiko et al., 2020).

Purse seine is a fishing tool aimed at catching groups of pelagic fish resources, however the success of catching purse seines is determined by many factors, both internal (design and construction) and external (availability of resources, weather conditions, currents, skills) in operations (Mahiswara, Budiarti, \& Baihaqi, 2013). The types of fish caught by purse seines are pelagic fish groups including SKJ and YFT (Aprilia et al., 2013).

Purse seine based at PPP Lampulo consists of two categories, namely purse seine with a one-day fishing system and a multi-day fishing system. Based on the time of operation, a ship with a one-day catch system is also divided into two types, namely a fleet that operates during the day and a fleet that operates at night. All ships are made of wood with the majority of Mitsubishi-branded engines. The length and width of the vessel ranged from 11.5 to $23.3,2.5-7.6$ and 0.7 0,2.75 meters, respectively.

Based on the Minister of Marine Affairs and Fisheries Regulation No. 05 / MEN / 2012 concerning Fishing Routes and Placement of Fishing Tools and Fishing Tools in the Fisheries Management Territory of the Republic of Indonesia, Article 21 states that the size of fishing boats is grouped into five: a) without a motor; b) motorized up to 5 GT; c) 5 - 10 GT motor; d) 10-30 GT motorized; e) motorized more than 30 GT. Based on the ministerial regulation, the composition of the purse seine fleets at PPS Lampulo is 
mostly over 30 GT. In 2018, the number of vessels recorded by PP Lampulo was 379 units, an increase of 9 units compared to 2017. The fishing fleet was <5 to $>100 \mathrm{GT}$ (Table 1) and was dominated by purse seines and fishing rods. Ring trawlers measure 5-131 GT and are predominantly 7 GT in size, while fishing boats are 5 - 19 GT in size and are predominantly 6 GT in size. The frequency of fishing fleet visits and carrying out unloading activities at PP Lampulo in 2018 reached 3,363 units and was dominated by ring trawlers. The number of fishing gear based at PP Lampulo in 2018 was 231 trawlers and 32 hand lines.

Table 1. Number Of Fishing Ship In PP Lampulo, 2017-2018

\begin{tabular}{llll}
\hline No & Ship Size & $\mathbf{2 0 1 7}$ & $\mathbf{2 0 1 8}$ \\
\hline 1 & 5 GT & 32 & 34 \\
2 & $5-10 \mathrm{GT}$ & 138 & 140 \\
3 & $10-20 \mathrm{GT}$ & 28 & 29 \\
4 & $20-30 \mathrm{GT}$ & 57 & 58 \\
5 & $30-50 \mathrm{GT}$ & 66 & 68 \\
6 & $50-100 \mathrm{GT}$ & 44 & 45 \\
7 & $>100 \mathrm{GT}$ & 5 & 5 \\
\hline Total & & 370 & 379
\end{tabular}

The characteristics of TTS fishing equipment depend on the ship because the number of fishing gear in a period does not necessarily have an impact on increasing the catch of the TTS (Firdaus, 2019). The use of fishing gear with the main target of TTS fishing rods does not always get the fish from the main target catch (Nugraha \& Setyadji, 2013). When catching TTS and mackerel, it turns out that they also get bycatch such as sharks and reef fish (Kurniawan et al. 2014). This shows that the large amount of TTS catch production is not only influenced by the number of fishing gears, but there are other factors such as the use of fishing ship, the seasonal nature of fishing and the number of fishing actors. Illegal, unreported and unregulated fishing (IUU fishing) factors are suspected to be one of the causes of statistical reporting that the amount of TTS production is not significant with the number of fishing gears used.

The construction of purse seine catching equipment based at PPS Kutaraja consists of a buoy, upper rope, net body, bag, lower rope, weights and a ring as a place for drawstring to tighten the bottom of the net. The length of purse seines varies from 450 - $1500 \mathrm{~m}$ and depth between 60 $700 \mathrm{~m}$. Themesh sizevaries between $3 / 4$ - 4 inches. The construction of FADs used by purse seine fishermen based at PPS Kutaraja consists of a buoy, main rope, attractor and ballast. Based on the results of the interview, the construction of FADs owned by KM. Inka Mina 806 has a total rope length of $\pm 700 \mathrm{~m}$. The rope is attached to the buoy made from styrofoam measuring $5 \times 3 \times 3 \mathrm{~m}$. Attractor using 100 dried nipah leaves. The concrete weight used is 16 pieces with a weight of $100 \mathrm{~kg}$ each. In addition to FADs, fishermen also use auxiliary tools in the form of lights, namely 16-20 PS 120 lamps mounted on the top of the boat, Global Positioning System (GPS) and Fish Finder as tools to help find fishing areas and fish schools (Figure 2).

As a fishing aid, FADs function to attract groups of fish to gather around them. In the short term FADs can increase catch production, efficiency and effectiveness of fishing operations. However, FADs can also have a negative impact on the sustainability of fish resource stocks due to a decrease in production caused by an increase in the number of FADs and fleet units at the same fishing location (Erfind et $a l ., 2012$ ). Tuna fish caught by FADs has a size that is not suitable for catching (baby tuna) (Nurani et al., 2008). These FADs are scattered in WPP 572 and 571 (Figure 3). The location of FADs as fishing grounds for fishermen is installed in waters within 50-190 nautical miles from the fishing base, the fishing location shown from the FAD installation site in recent years has become increasingly distant (PPS Lampulo) (Salmarika et al., 2019). There has been a shift in the fishing area (indication of range collapse) (Aprilia et al., 2013).

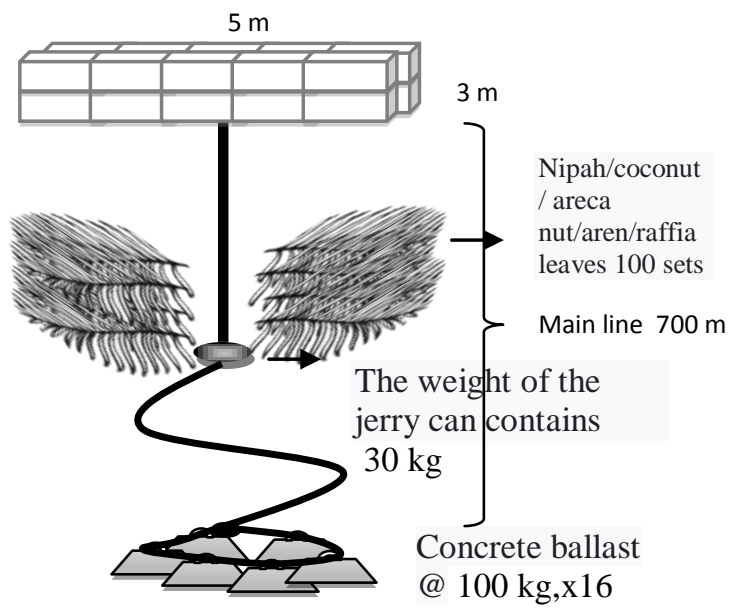

Figure 2. Construction of FADs Used by Purse Seine Fleets Based in PPS Kutaraja

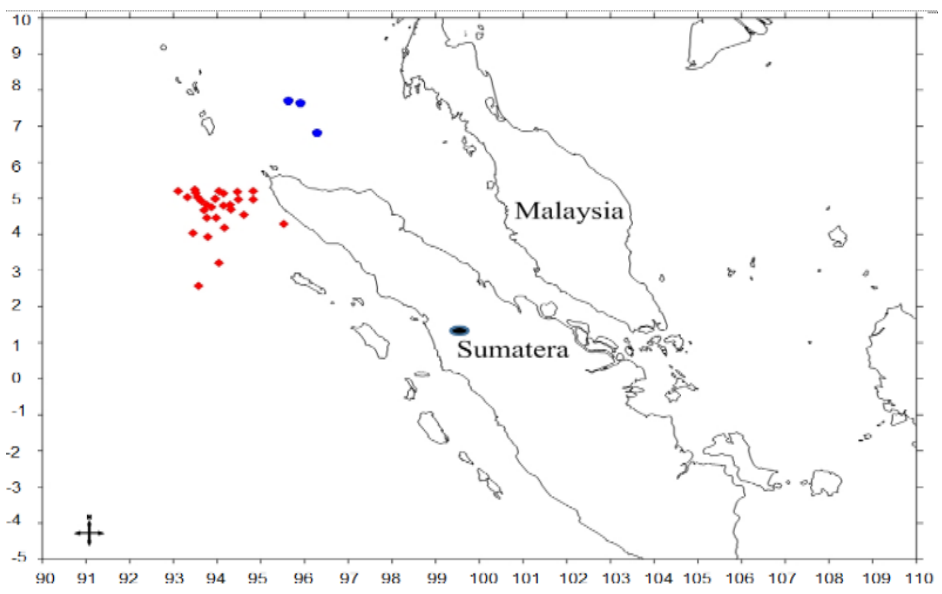

Figure 3. Position Of The Purse Seine Fads Based At PPS Kutaraja

Each fishing area consists of several FADs which are used in groups. Based on an understanding of water conditions and the rules for installing FADs, the proper placement of FADs, installation of FADs refers to the variability ofchlorophyll-a and sea surface temperature and takes into account the rules contained in KepmenKPN No.30 / 2004. The distance design for each FAD is 10 nautical miles, installed parallel to the coastline and not zigzagging so as not to interfere with shipping lanes (Nurani et al., 2014). The trend of increasing catch productivity occurs when chlorophyll-a conditions are high with low sea surface temperatures (E. Nurdin et al., 2018). 


\section{TCT Cath Composition}

Production of TTS at PPS Kutaraja is dominated by 2 fishing gears, namely purse seines and hand lines. The highest total fish catch within 10 months were SKJ, BLT, YFT and KAW. The total fish catch based on the Kutaraja Ocean Fishing Port (PPS) during 2020 is presented in Figure 4. Except for May-June there was no data collection activity as a result of the pandemic Covid-19. TTS fishing production in Indonesia as a whole has continued to increase from 2000 to 2015. The amount of SKJ production is greater than that of Tuna (Firdaus, 2019). SKJ is mostly caught at $27.4^{\circ} \mathrm{C}$, it is known that the average sea surface temperature in Aceh is around $27.24{ }^{\circ} \mathrm{C}$ and the SST in the Aqua MODIS image is around $28.21{ }^{\circ} \mathrm{C}$ in the east - west transition season (Habib et al., 2019). The marine environment in northern Aceh and Pulo Aceh is thought to be a suitable area for the development of skipjack tuna (Aprilia et al., 2013)

The presence of skipjack tuna is influenced by water productivity, one of which is marked by the distribution of chlorophyll-a, the average chlorophyll-a ranges from 0,23 $\mathrm{mg} / \mathrm{m} 3$, with a variation of $0.10-1.30 \mathrm{mg} / \mathrm{m} 3$ which is spread almost evenly in the waters of Aceh and the Strait of Malacca (Habib EY, Nofrizal, \& Mubarak, 2018). The catch composition at PPS Kuta Raja is dominated by $99 \%$ target fish, fishing areas are getting further away, and there are ETP (Endangered, Threatened, and Protected species) caught. Based on these EAFM indicators, the status of tuna resource management in this location is included in the 'medium' category, so that 'prudent' management measures need to be applied diterapkan (Salmarika et al., 2019).

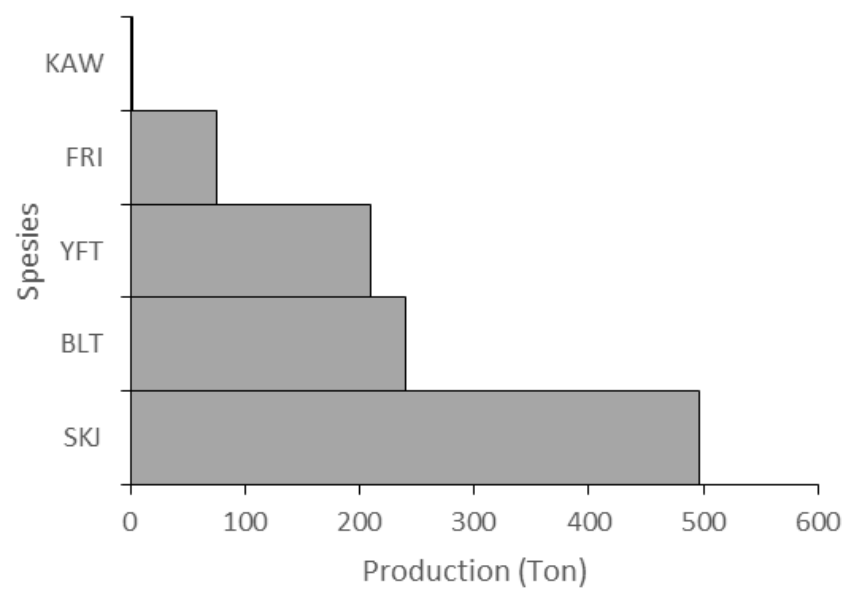

Figure 4. Composition of the catch of TTS at PPS Kuta Raja, Aceh

\section{Estimated Catch Results}

Based on enumeration results in 2020 the estimated total TCT production at PPS Kuta Raja is 11,520 tonnes. The highest estimates were SKJ: 5,802 tons, BLT: 2814 tons, YFT: 2,452 tons, FRI: 448 tons, and KAW: 1,745 tons. Monthly estimation results indicate that the catch is fluctuating. The contribution of the sampling percentage and the size of the estimation of perspectives is presented in Table 2.

Production factors that can increase the production produced at PPS Kuta Raja are influenced by the engine power of the ship, the height of the net, the number of crew members, the number of lights, and the cost of supplies. Another factor is the environment or fishing ground conditions such as weather, fishing season, resource conditions and April water conditions (Aprilia et al., 2013). Fishery production caught in the West Indian Ocean Sumatra is smaller than South Java because fishing pressure is higher, so that the mortality rate due to fishing is higher (Zedta et al., 2018).

Table 2. Catch Based On The Kutaraja Ocean Fishing Port (PPS) During 2020

\begin{tabular}{crrrrr}
\hline \multirow{2}{*}{ Month } & \multicolumn{5}{c}{ Estimated(Kg) } \\
\cline { 2 - 6 } & \multicolumn{1}{c}{ BLT } & \multicolumn{1}{c}{ FRI } & \multicolumn{1}{c}{ SKJ } & \multicolumn{1}{c}{ YFT } & KAW \\
\hline JAN & 145.935 & 1.157 .858 & 1.142 .065 & 548.251 & \\
FEB & 136.640 & 376.833 & 808.671 & 346.640 & \\
MAR & 459.387 & 486.850 & 816.410 & 239.430 & \\
APR & 549.281 & 617.372 & 292.430 & 173.097 & 1.7719 \\
MEI & & & & & \\
JUN & & & & & \\
JUL & 958.770 & 336.896 & 1.430 .966 & 453.667 & \\
AGS & 784.863 & 1.561 .441 & 1.069 .636 & 676.665 & \\
SEP & 35.486 & 16.940 & 70.488 & 28.127 & 770 \\
OKT & 1.624 & 2.046 & 9.520 & 3.759 & \\
NOV & 6.695 & 387.089 & 356.827 & 179.434 & \\
DEC & 2.282 & 21.130 & 136.666 & 35.751 & \\
\hline TOTAL & 2.814 .693 & 448.078 & 5.802 .748 & 2.452 .754 & 1.745 \\
\hline
\end{tabular}

\section{Characteristics of Catch Results}

Analysis of the length distribution of the TCT commodity based at PPS Lampulo during 2020 is presented in Figure 5. The recording of fish biological samples was carried out on 3034 samples of SKJ. From the observations, it was found that the length class of the SKJ that was caught was 19$56 \mathrm{cmFL}$. The size of the first maturity of gonads $(\mathrm{Lm})$ is one of the parameters in determining the smallest size of fish fit to be caught, and to determine population development in a water (Dahlan et al., 2019). SKJ caught in the southern hinda ocean of Bali has an Lm value of $44.7 \mathrm{cmFL}$ (Hartaty \& Arnenda, 2019). So that $98.81 \%$ of SKJs caught in PPS Kuta Raja are not yet ripe for goad or have not yet spawned. When viewed from the maturity of the gonads SKJ in the Indian Ocean, $43 \%$ have matured gonads (Jatmiko et al., 2015). It is known that SKJ spawns throughout the year and eggs are released gradually over a long period of time (partial spawner) (Effendie, 2002). The northern waters of Aceh and Pulo Aceh are thought to be suitable areas for SKJ (Aprilia et al., 2013). So that there should be no problem for its regeneration in nature, but the results showed that the caught SKJ were dominated by immature gonads.

The recording of fish biological samples was carried out on 1073 BLTs. From the observations, it was found that the length class caught was $15-37 \mathrm{cmFL}$. The length of first maturity of BLT gonads (Lm) caught in the western Sumatra Ocean was $27.16 \mathrm{cmFL}$ (Tampubolon et al., 2016). So that $96.55 \%$ of BLT have not yet matured gonads and have not spawned. The exploitation rate (E) of lisong cob in West Sumatra is at a moderate exploitation rate, and the long

Co Copyright by Saintek Perikanan: Indonesian Journal of Fisheries Science and Technology, ISSN : 1858-4748 
frequency distribution has a mode value in the range of 25-26 cm FL which does not show a significant shift every month (Noegroho \& Chodrijah, 2015).

The recording of fish biology samples was conducted against 1314 YFT samples. From the observations obtained that the long class caught is $20-152 \mathrm{cmFL}$. The length of the first mature gonads (Lm) YFT in the indian ocean is $94.6 \mathrm{cmFL}$ (Arnenda et al., 2018). So that $99.08 \%$ of YFT caught are not yet ripe for gonads and have not yet spawned. YFT is the main catch of hand line fishermen who operate in the waters around the deep sea FADs (Muhammad \& Barata, 2012). The lifespan of YFT is estimated to be 3 years. When the fish is about 4 years old, yellowfin fish reach a length of 137-145 cmFL (Sumadhiharga, 2009).

FRI biological samples were taken from 636 samples. From the observations, it was found that the length class caught was $19-42 \mathrm{cmFL}$. Thelength of the first time to ripen cobs of cobs in the Indian Ocean west of Sumatra is 32.8 cmFL (Tampubolon et al., 2016). So as much as $86 \%$ of FRI are immature gonads and have not spawned.

KAW samples were 47 samples, with the length class caught was 19-42 cmFL. The gonad maturity (Lm) length of KAW in the Indian Ocean west of Sumatra is 42.032cmFL (Arnenda et al., 2020). So as many as $97.87 \%$ of KAW caught at PPS Kuta Raja have not yet matured gonads

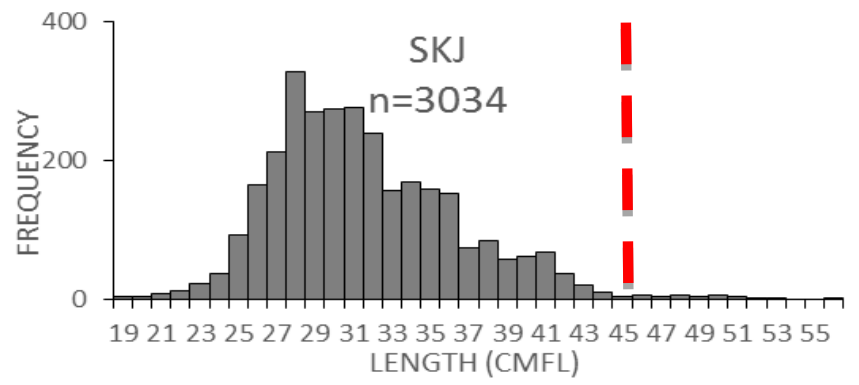

(a)

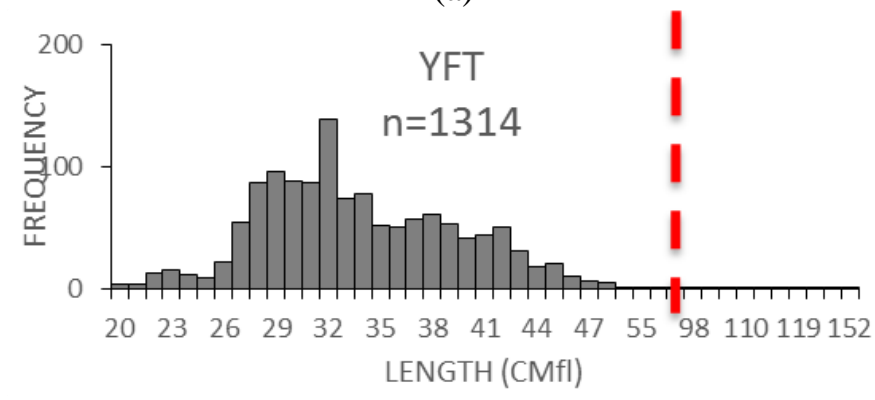

(c) and have never spawned. Komo tuna is able to reach the fork length and maximum age of $80.75 \mathrm{~cm}$ and 4.29 years, respectively, the fork length reaches $47.6 \mathrm{~cm}, 66.4 \mathrm{~cm}, 75.8$ $\mathrm{cm}$, and 80.4 at age. 1, 2, 3 and 4 consecutive years (Wujdi et al., 2020)

The fish caught in FADs show relatively the same size every month, this is thought to be due to the fishing area around FADs. The fish that are in FAD tend to be in schooling, so that the size caught is relatively uniform. These fish are attracted to and associated with FAD temporarily and are not yet ripe for gonads(Noegroho \& Chodrijah, 2015). The condition of small-scale capture fisheries that are multigear and multispecies causes increased pressure on the condition of fish resources (Sari et al.,, 2015). Sehingga keseluruhan hasil tangkapan di PPS Kuta Raja hampir 100\% merupakan ikna belum matang gonad. Eksploitasi terhadap juvenille ikan secara terus menerus dengan alat tangkap purse seine yang tidak selektif akan menyebabkan kelestarian terancam. Sehingga sangat perlu adanya evaluasi mengenai pengunaan alat tangkapnya atau perizinan rumponnya. Kegiatan penangkapan ikan di PPS Kuta Raja snagat mengkhawatirkan keberlanjutannya apabila dilihat dari strukturan ikan ynag tertangkap adalah belum dewasa.

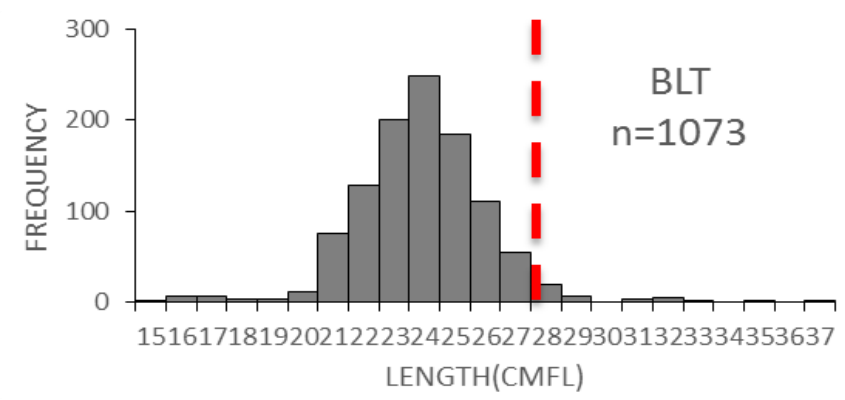

(b)

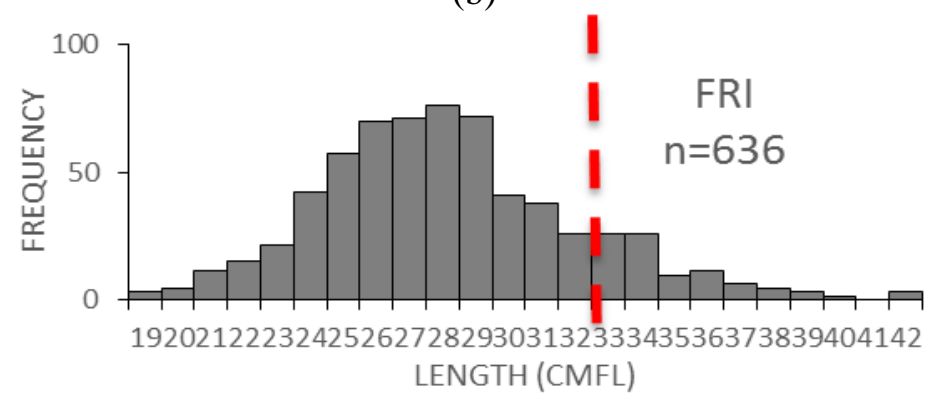

(d)

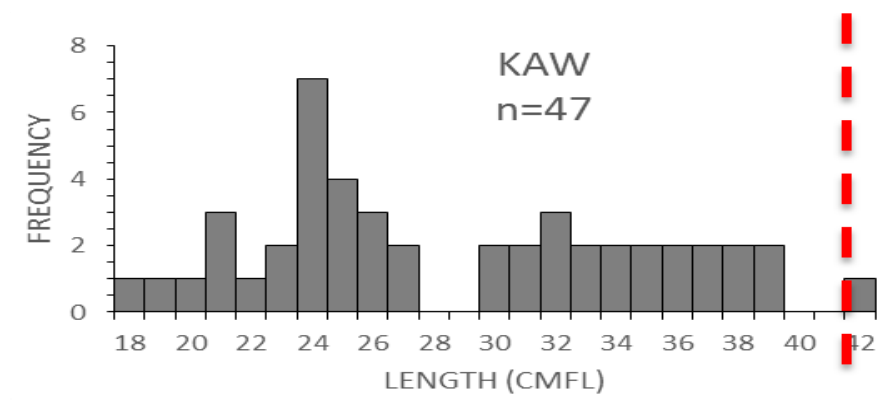

(e)

Figure 5. Distribution of TTS in PPS Kuta Raja, Aceh (a) SKJ, (b) BLT, (c) YFT, (d) FRI, and (e) KAW 
The results of the analysis of the length-weight relationship to 5 TCT species based at the Lampulo PPS during 2020 are presented in Figure 6.The pattern of lengthweight relationship SKJ relationships is obtained by the equation $\mathrm{W}=0.0167 \mathrm{~L}^{2.9894}$ with the coefficient of determination $\left(\mathrm{r}^{2}\right)=0.858$ with a b value of $2.9894(<3)$ andvalue $a$ of 0.016 . The growth pattern is negative allometric, where the length growth is slower than the weight growth.

The pattern of length-weight relationship BLT obtained by the equation $\mathrm{W}=0.0081 \mathrm{~L}^{3.17}$ with the coefficient of determination $\left(\mathrm{r}^{2}\right)=0.8307$ with a b value of $3.17(>3)$ andvalue $a$ of 0.008 . The growth pattern is positive allometric, where the length growth is more rapid growth of weight. This is consistent with previous research where BLT in the Indian Ocean, West Sumatra, is allometrically positive (Tampubolon et al., 2016).

Length-weight relationship of YFT obtained by the equation $\mathrm{W}=0.0265 \mathrm{~L}^{2.8855}$ with a coefficient of determination $\left(\mathrm{r}^{2}\right)=0.8997$ with $\mathrm{a} b$ value of $2.855(<3)$ andvalue $a$ of 0.0265 . negative allometric growth, where the length growth is slower than the weight growth. The YFT growth pattern in the eastern hinida high school is also positive allometric (Muhammad \& Barata, 2012)

Length-weight relationship of FRI is obtained by the equation $\mathrm{W}=0.0108 \mathrm{~L}^{3.1023}$ with a coefficient of determination

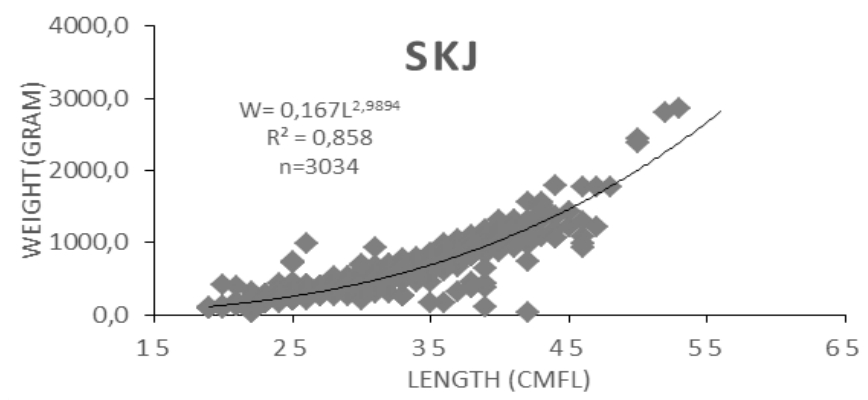

(a)

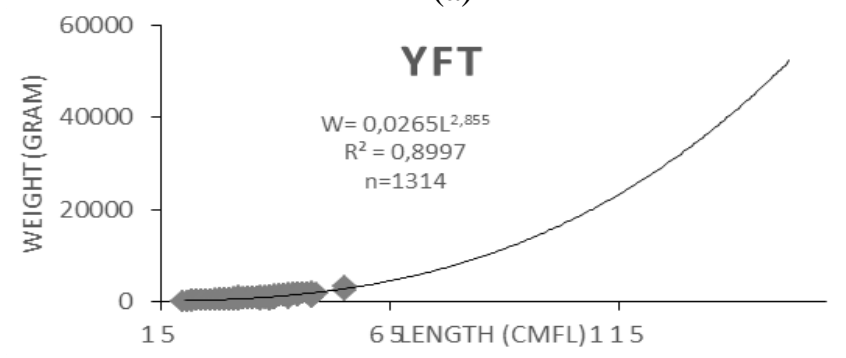

(c) $\left(\mathrm{r}^{2}\right)=0.9455$ with a $\mathrm{b}$ value of 3.1023 (> 3) andvalue $a$ of 0.0108 . The growth pattern is positive allometric, where the length growth is faster than the weight growth. This is consistent with previous research where the FRI in the Indian Ocean of West Sumatra is allometrically positive (Tampubolon et al., 2016).

The pattern of length-weight relationship KAW obtained by the equation $\mathrm{W}=0.0098 \mathrm{~L}^{3.525}$ with the coefficient of determination $\left(r^{2}\right)=0.9863$ with a value of $b$ of $3.525(>3)$ andvalue $a$ of 0.0098 . The growth pattern is positive allometric, where the length growth is faster than the weight growth. The growth pattern of KAW in the Indian Ocean of West Sumatra has a positive allometric character in fishing using purse seine fishing gear (Arnenda et al., 2020).

Growth patterns are also influenced by the characteristics of deep waters to support the availability of food and suitable habitat (Nugroho et al., 2018). The availability of food taken will affect the growth, maturity of each individual and the success of his life (Effendie, 2002). Length growth greatly affects weight growth due to two factors, the availability of food resources and the body shape of fish with stomach contents (Lelono \& Bintoro, 2019). Another thing that affects the growth pattern is biological factors, namely gonad development, where the development of female gonads matures faster than the development of male gonads (Johnson \& Tamatamah, 2017)

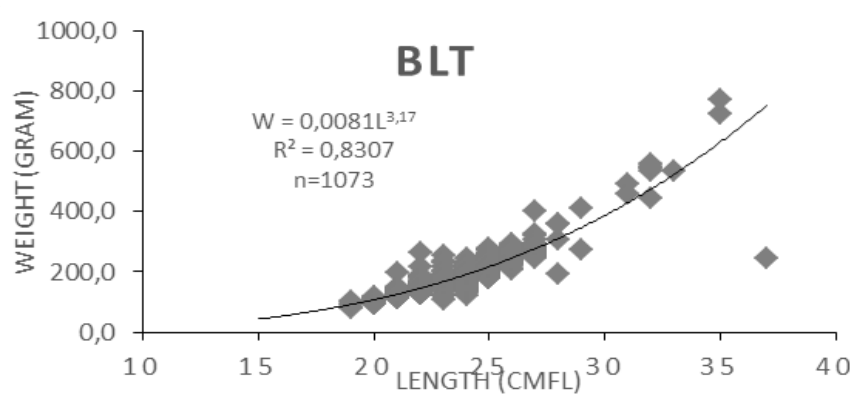

(b)

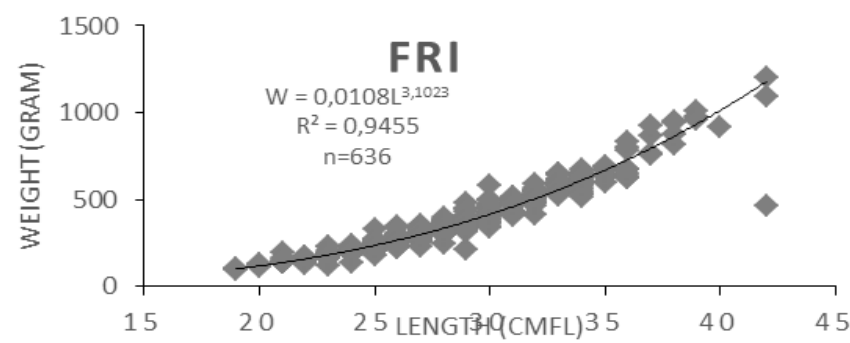

(d)

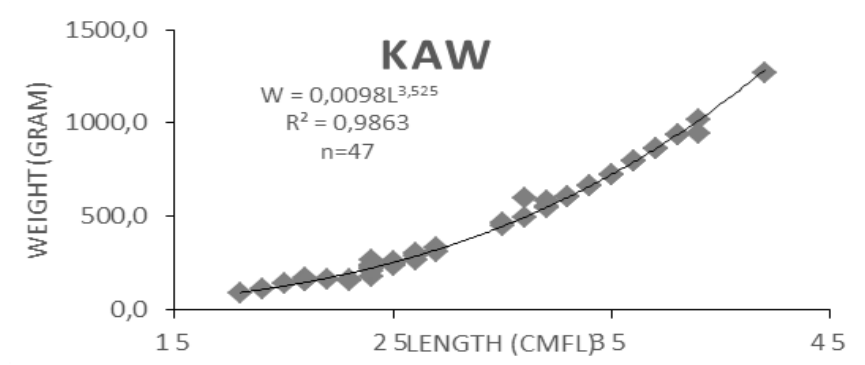

(e)

Figure 6. TTS Legth-Weight Relationship in PPS Kuta Raja, Aceh Aceh (a) SKJ, (b) BLT, (c) YFT, (d) FRI, and (e) KAW 
The catch rate pattern of PP Lampulo shows fluctuating results. Overall experiencing the same CPUE pattern, namely the first highest peak in March / April, then experiencing the second peak in August. Meanwhile, the lowest CPUE occurred in October. The results showed that SKJ had the highest CPUE value of 5.04 tonnes / trip in August, and had the lowest CPUE value of 0.05 tonnes / trip in October.BLT had the highest CPUE value of 3.70 tons / trip in August, and had the lowest CPUE value of 0.01 tons / trip in October.

YFT had the highest CPUE value of 3.19 tonnes / trip in August, and had the lowest CPUE value of 0.02 tonnes / trip in October. Analysis of Catch Per Unit Effort (CPUE) of yellowfin tuna is used to determine the abundance of yellowfin tuna in a waters and the level of utilization with the CPUE value tends to fluctuate in each virtual fish landing area (Agustina, Setyadji, \& Tampubolon, 2019). FRI had the highest CPUE value of 1.01 ton / trip in August, and had the lowest CPUE value of 0.002 ton / trip in October.

The four monthly CPUE distribution patterns have the same results, where in August it reaches the highest CPUE and October reaches the lowest CPUE value. This is because the catch is carried out in the same FAD area, so the composition and effort of the catch has almost the same fluctuation. These fish are attracted to and associated with each other (Noegroho \& Chodrijah, 2015).

The yield per catch per unit effort-CPUE nominal (non-standardized CPUE) nominal purse seine CPUE decreased from year to year (Widodo, Hargiyatno, Anggawangsa, \& Wudianto, 2020). The CPUE value is influenced by several factors, one of which is the influence of the season, the presence of large waves and winds resulting in a decrease in fishing effort (Sulistyaningsih et al., dan 2017). Fishing factors and water conditions also greatly affect the CPUE value, and fishing season in west Sumatra (Hidayat, Noegroho, \& Chodrijah, 2018). The decrease in the value of the CPUE is the impact of a decrease in the number of trips and the number of fishing ship (Dian A.N.N. Dewi; Iqbal Ali Husni, 2016). On the other hand, changes in competition are thought to have an impact on the productivity of the catch. Based on the results of CPUE calculations, it can be seen that the productivity of all fishing gear changes that occurs as a result of shifting the catch (Sari et al., 2015).

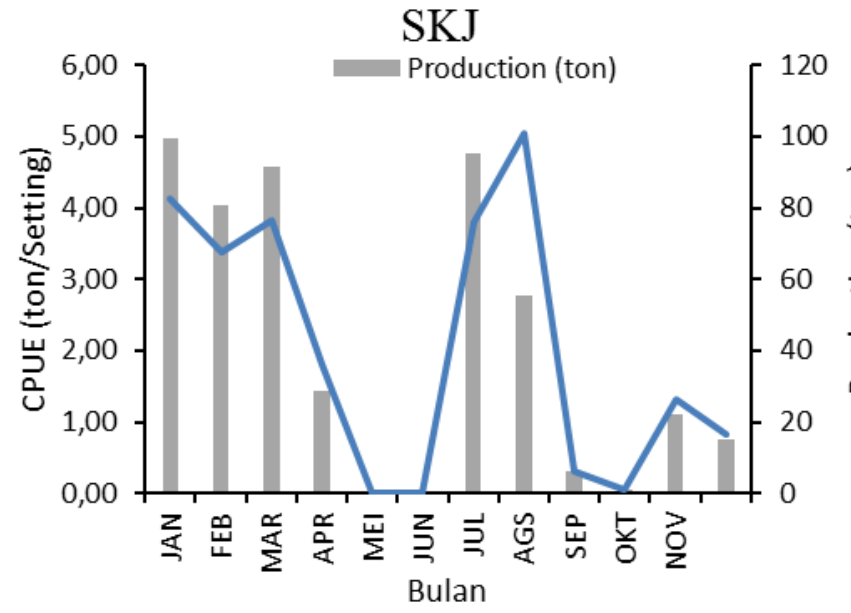

(a)

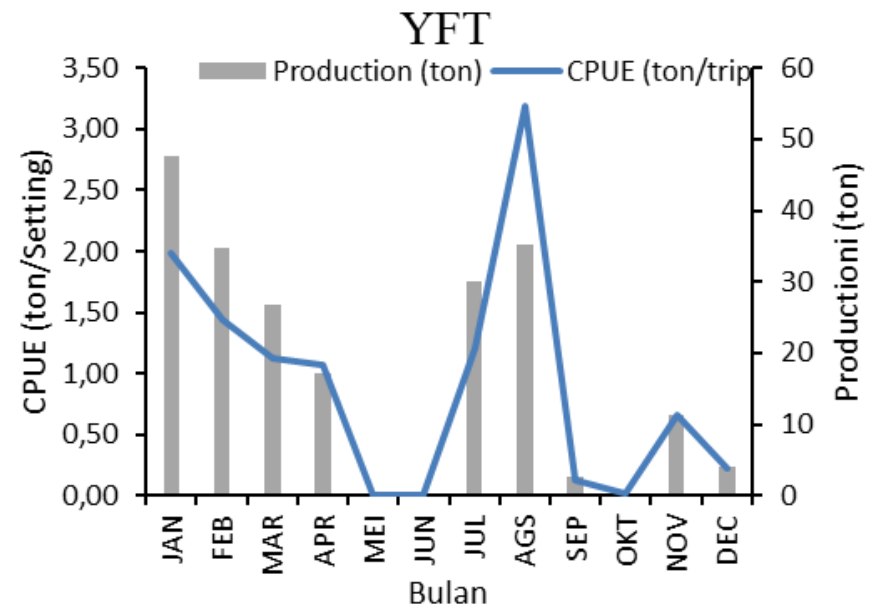

(c)

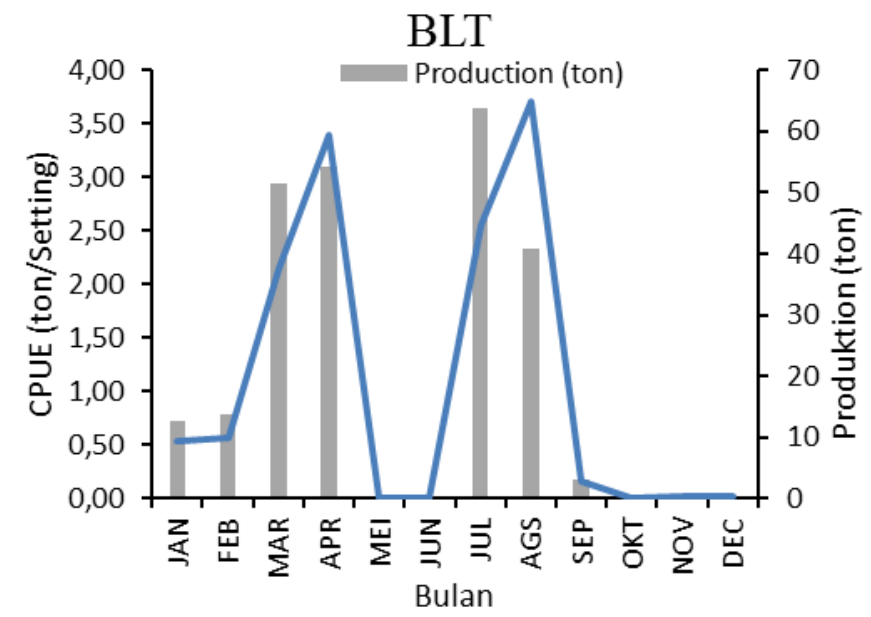

(b)

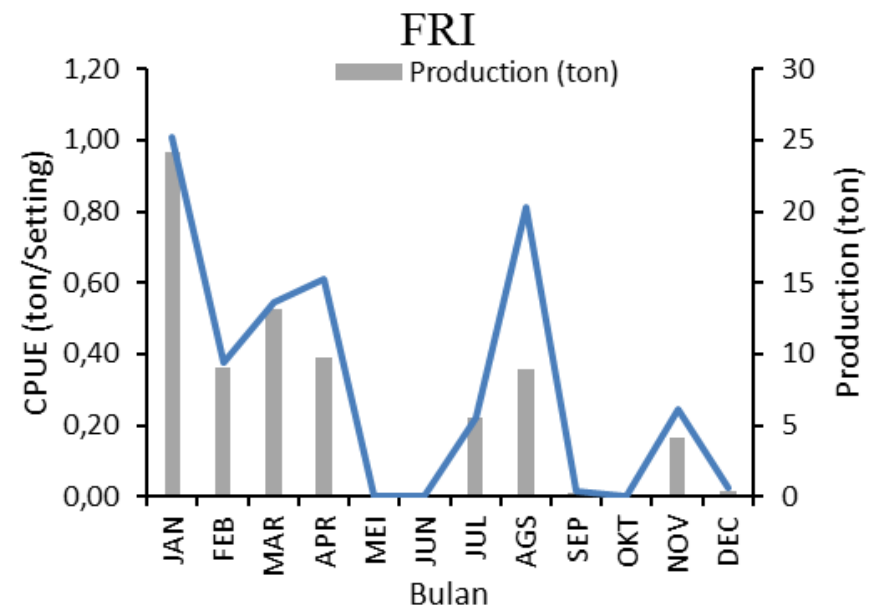

(d)

Figure 7. CPUE TTS in PPS Kuta Raja, Aceh (a) Skipjack Tuna (Katsuwonus pelamis) (SKJ), (b) Bullet Tuna (Auxis rochei)(BLT), (c)Yellow fin (Thunnus albacares) (YFT), dan (d)Tongkol Krai (Auxis thazard) (FRI) 


\section{CONCLUSION}

The results showed that the production of TCT at PPS Kutaraja is dominated by 2 fishing gears, namely purse seines and hand lines. The estimated total TCT production at PPS Kuta Raja reached 11,520 tons. The highest total estimated fish catch is skipjack tuna (Katsuwonus pelamis) (SKJ) 5,802 tons, Bullet tuna (Auxis rochei)(BLT) 2814 tons, Yellow fin (Thunnus albacares) (YFT) 2,452 tons, Krai Tongkol (Auxis thazard) (FRI) 448 tons, and Eastern little tuna (Euthynnus affinis) 1,745 tonnes. (KAW). All of the fish caught were dominated by immature fish. So it is very necessary to evaluate the use of fishing gear or the licensing of FADs. The monthly CPUE distribution pattern is the same, where in August it reaches the highest CPUE and in October it reaches the lowest CPUE value.

\section{ACKNOWLEDGMENT}

Thanks to Research Institute of Tuna Fisheries (RITF), this research is part of the RITF Workshop T.A.2020. Researchers at RITF. PPS Kutaraja, Syahbandar Kutaraja. This research is part of the Ta Tuna Fisheries Research Workshop. 2019.Thanks to the Head of Tuna Fisheries Research Workshop for the period 2016-2020, Mr. Zulkarnaen Fahmi, S.Pi., M.Si. The award was also given to the Head of Research Institute of Tuna Fisheries (RITF), for the period 2021 Mrs. Ririk Kartika Sulistyaningsih, S.Pi., M.App.Sc. Thank you for guidance from Aried Wudjie, S.Pi. and Fathur Rochman, S.Pi., M.Si. Thank you authors to all researchers, enumerators and analysts of Loka Tuna Fisheries Research during the study. Thank you to all those who have helped the implementation of this research.

\section{REFERENCES}

Agustina, M., Setyadji, B., \& Tampubolon, P. A. R. P. (2019). Perikanan Tuna Sirip Kuning (Thunnus albacares Bonnaterre, 1788) Pada Armada Tonda Di Samudera Hindia Selatan Jawa. Bawal, 11(3), 161. Https://Doi.Org/10.15578/Bawal.11.3.2019.161-173

Aprilia, R. M., Mustaruddin, M., Wiyono, E. S., \& Zulbainarni, N. (2013). Analisis Efisiensi Unit Penangkapan Pukat Cincin Di Pelabuhan Perikanan Pantai Lampulo Banda Aceh. Jurnal Teknologi Perikanan dan Kelautan, 4(1), 9-20. Https://Doi.Org/10.24319/Jtpk.4.9-20

Arnenda, Gussasta L, Setyadji, B., Intan, N., \& Sara, I. M. (2020). Biological Aspects , Catching Aspects and Fishing Ground of Eastern Little Tuna or Kawakawa ( Euthynnus affinis (Cantor , 1849 )) Based on The Fishing Gear At WPP 572, SAINTEK Perikanan,16(3), 199-207.

Arnenda, Gussasta Levi, Jatmiko, I., \& Kusdinar, A. (2018). Biologi Reproduksi Madidihang (Thunnus albacares Bonnaterre, 1788) Di Samudra Hindia Bagian Timur. Jurnal Kelautan Dan Perikanan Terapan, 1(2), 55-62.

Dahlan, M. A., Yunus, B., Umar, M. T., \& Nur, M. (2019). Musim Pemijahan Ikan Tongkol Lisong (Auxis rochei Risso,1810) di Perairan Majene Sulawesi Barat
Spawning. Proceeding Simposium Nasional Kelautan dan Perikanan, 6, 177-180.

Dian A.N.N. Dewi; Iqbal Ali Husni. (2016). Penangkapan Purse Seine di Pelabuhan Perikanan Nusantara Pekalongan. Fisheries And Marine Science, 2(2), 68-74.

Effendie, M. . (2002). Biologi Perikanan. Yayasan Pustaka Nusantara. Yogyakarta.

Firdaus, M. (2019). Profil Perikanan Tuna dan Cakalang di Indonesia The Profile Of Tuna and Cakalang Fishery In Indonesia. Buletin Ilmiah Marina Sosial Ekonomi Kelautan dan Perikanan, (021), 23-32.

Habib E., M., Nofrizal, \& Mubarak. (2018). Pengaruh Sebaran Klorofil-A Terhadap Hasil Tangkapan Ikan Cakalang (Katsuwonus pelamis ) pada Pengoperasian Purse Seine di Perairan Aceh. Universitas Riau, 46(1), 56-63.

Habib, M., Nofrizal, \& Mubarak. (2019). Sebaran SPL Kaitannya dengan Hasil Tangkapan Ikan Cakalang (Katsuwonus pelamis) di Perairan Aceh. Marine Fisheries, 10(1), 11-22.

Hartaty, H., \& Arnenda, G. L. (2019). Penentuan Ukuran Pertama Kali Matang Gonad ( Lm ) Cakalang ( Katsuwonus pelamis Linnaeus , 1758 ) Di Samudra Hindia Selatan Bali. Jurnal Penelitian Perikanan Indonesia, 25(2), 135-145.

Herdiana, Y., Yulianto, I., Campbell, S.J., \& Baird, A.H. (2010). Membangun Puing Harapan. Wildlife conservation Society - Indonesian Marine Programme

Hidayat, T., Noegroho, T., \& Chodrijah, U. (2018). Biologi Ikan Tongkol Komo (Euthynnus affinis) di Laut Jawa. Jurnal Pengelolaan Perikanan Tropis, 02, 30-36.

Jatmiko, I., Catur, S., \& Fahmi, Z. (2020). Karakteristik Perikanan Pukat Cincin Pelagis Besar di Perairan Samudra Hindia (WPPNRI 572 Dan 573). Jurnal Penelitian Perikanan Indonesia, 26, 37-46.

Jatmiko, I., Hartaty, H., \& Bahtiar, A. (2015). Biologi Reproduksi Ikan Cakalang (Katsuwonus pelamis) di Samudera Hindia Bagian Timur. Bawal, 7(140), 87-94.

Johnson, M. G., \& Tamatamah, A. R. (2017). Length Frequency Distribution, Mortality Rate And Reproductive Biology Of Kawakawa (Euthynnnus affinis-Cantor,1849) In The Coastal Waters Of Tanzania. Pjbs: Pakistan Journal Of Biological Science, 16(21), 68-70.

Juanda, \& Martunis. (2014). Analisa Kelayakan Finansial Pengembangan Cold Storage Plant di Pelabuhan Perikanan Lampulo Baru Banda Aceh. Jurnal Teknologi dan Industri Pertanian Indonesia, 6(1), 18-21. Https://Doi.Org/10.17969/Jtipi.V6i1.1985

[KKP] Kementerian Kelautan Dan Perikanan. (2012). Peraturan Menteri Kelautan Dan Perikanan Republik Indonesia Nomor Per.05/Men/2012 Tentang Perubahan Kedua Atas Peraturan Menteri Kelautan Dan Perikanan Nomor Per.02/Men/2011 Tentang Jalur Penangkapan Ikan Dan Penempatan Alat Penangkapan Ikan Dan Alat Bantu Penangkapan Ikan Di Wilayah Pengelolaan Perikanan Negara Republik Indonesia. KKP. Jakarta (ID).

Lelono, T. D., \& Bintoro, G. (2019). Population Dynamics And Feeding Habits Of Euthynnus Affinis, Auxis Thazard, And Auxis Rochei In South Coast Of East Java 
Waters. Iop Conference Series: Earth And Environmental Science, 370(1), 1-8. Https://Doi.Org/10.1088/1755-1315/370/1/012054

Liestiana, H., Ghofar, A., \& Rudiyanti, S. (2015). Aspek Biologi Ikan Layang (Decapterus Macrosoma) Yang Didaratkan Di Ppp Sadeng, Gunungkidul, Yogyakarta. Diponegoro Journal Of Maquares, 4(4), 10-18.

Mahiswara, Budiarti, T. W., \& Baihaqi. (2013). Karakteristik Teknis Alat Tangkap Pukat Cincin Di Perairan Teluk Apar, Kabupaten Paser - Kalimantan Timur. Jurnal Penelitian Perikanan Indonesia, 19(1), 1-7.

Mccluske Sm, \& Lewinson Rl. (2008). Quantifying Fishing Effort: A Synthesis Of Current Methods And Their Applications. Fish And Fisheries, 9(1), 188-200.

Mertha, I. G. S., Nurhuda, M., \& Nasrullah, A. (2017). Perkembangan Perikanan Tuna Di Pelabuhanratu. Jurnal Penelitian Perikanan Indonesia, 12(2), 117-127. Https://Doi.Org/10.15578/Jppi.12.2.2006.117-127

Moreno, Guillermo;Herrera, M. (2013). Estimation Of Fishing Capacity By Tuna Fishing Fleets In The Indian Ocean. Iotc-2013-Sc16-Inf04, 4:11, 77.

Muhammad, N., \& Barata, A. (2012). Stuktur Ukuran Ikan Madidihang (Thunnus Albacares) Yang Tertangkap Pancing Ulur Di Sekitar Rumpon Samudera Hindia Selatan Bali Dan Lombok. Bawal, 4(3), 161-167.

Noegroho, T., \& Chodrijah, U. (2015). Parameter Populasi Dan Pola Rekruitmen Ikan Tongkol Lisong (Auxis Rochei Risso 1810) Di Perairan Barat Sumatera. Bawal, 7(3), 129-136.

Nugraha, B., \& Setyadji, B. (2013). Kebijakan Pengelolaan Hasil Tangkapan Sampingan Tuna Longline Di Samudera Hindia, Jurnal Kebijkan Perikanan Indonesia, 5(2), 67-71.

Nugroho, S. C., Jatmiko, I., \& Wujdi, A. (2018). Pola Pertumbuhan Dan Faktor Kondisi Madidihang, Thunnus Albacares (Bonnaterre, 1788) Di Samudra Hindia Bagian Timur. Jurnal Iktiologi Indonesia, 18(1), 13. Https://Doi.Org/10.32491/Jii.V18i1.371

Nurani, T. W., Wisudo, S. H., Wahyuningrum, P. I., \& Arhatin, R. E. (2014). Model Pengembangan Rumpon Sebagai Alat Bantu Dalam Pemanfaatan Sumber Daya Ikan Tuna Secara Berkelanjutan. Jurnal Ilmu Pertanian Indonesia, 19(4), 57-65.

Nurdin, E., Panggabean, A. S., \& Restianingsih, Y. H. (2018). Pengaruh Parameter Oseanografi Terhadap Hasil Tangkapan Armada Tonda Di Sekitar Rumpon Di Palabuhanratu. Jurnal Penelitian Perikanan Indonesia, 24(2), 117-126.

Nurdin, Erfind, Taurusman, A. Azbas, \& Yusfiandani, R.
(2012). Optimasi Jumlah Rumpon, Unit Armada Dan Musim Penangkapan Perikanan Tuna Di Perairan Prigi, Jawa Timur. Jurnal Litkayasa Perikanan Indonesia, 18, 53-60.

Salmarika, Tauruman, A. A., \& Wisudo, H. S. (2019). Status Pengelolaan Sumber Daya Ikan Tongkol Di Perairan Samudera Hindia Berbasis Pendaratan Pukat Cincin Di Pelabuhan Perikanan Samudera Lampulo, Aceh: Suatu Pendekatan Ekosistem. Bawal, 24(4), 263-272.

Sari, W. K., Wiyono, E. S., \& Yusfiandayani, R. (2015). Kompetisi Perikanan Tangkap Skala Kecil Di Pelabuhan Perikanan Nusantara ( Ppn ) Prigi Jawa Timur. J. Lit. Perikan. Ind., 221-228.

Sulistyaningsih, R. K., Barata, A., \& Siregar, K. (2011) Perikanan Pancing Ulur Tuna Di Kedonganan, Bali. Jurnal Penelitian Perikanan Indonesia, 17(3), 185-191.

Sumadhiharga, O.K. 2009. Ikan Tuna. Pusat Penelitian Oseanografi. Lembaga Ilmu Pengetahuan Indonesia. Jakarta.

Supriatna, A., Hascaryo, B., Wisudo, S. H., Baskoro, M., \& Nikijuluw, V. P. (2014). Model Rantai Nilai Pengembangan Perikanan Tuna, Tongkol, Dan Cakalang Di Indonesia. Jurnal Pengolahan Hasil Perikanan Indonesia, 17(2), 144-155.

Tampubolon, P. A. R. P., Novianto, D., Hartaty, H., Kurniawan, R., Setyadji, B., \& Nugraha, B. (2016). Size Distribution And Reproductive Aspects Of Auxis Spp. From West Coast Sumatera, Eastern Indian Ocean. Research Institute For Tuna Fisheries, Ministry Of Marine Affairs And Fisheries, Indonesia, 1--8.

Widodo, A. A., Hargiyatno, I. T., Anggawangsa, R. F., \& Wudianto. (2020). Pemanfaatan Dan Pengelolaan Tuna Neritik Di Wilayah Pengelolaan Perikanan Negara Republik Indonesia ( Wppnri ) 573 ( Studi Kasus Perikanan Tuna Neritik Berbasis Di Ppn PrigiTrenggalek-Jawa Timur ). Jurnal Penelitian Perikanan Indonesia, 26, 11-20.

Wujdi, A., Hartaty, H., \& Setyadji, B. (2020). Estimasi Parameter Populasi Dan Rasio Potensi Pemijahan Tongkol Komo (Euthynnus Affinis, Cantor 1849) Di Perairan Selatan Lombok. Jurnal Penelitian Perikanan Indonesia, 26(2), 93 Https://Doi.Org/10.15578/Jppi.26.2.2020.93-107

Zedta, R. R., Rintar Pt, P. A., \& Novianto, D. N. (2018). Estimasi Parameter Populasi Ikan Cakalang (Katsuwonus Pelamis, Linnaeus, 1758) Di Perairan Samudra Hindia. Bawal, 9(3), 163 Https://Doi.Org/10.15578/Bawal.9.3.2017.163-173 